\title{
IMPLEMENTATION RECONSTRUCTION OF SHARING PROFIT AND LOSSES IN MURABAHAH FINANCING IN SHARIA BANK INDONESIA BASED ON ISLAMIC JUSTICE PERSPECTIVE
}

\author{
Ahmad Supriyadi \\ Lecturer at STAIN Kudus \\ E-mail : supriyadi515@yahoo.com
}

\begin{abstract}
Sharia Bank is a bank that has a special characteristic in its operations by applying the principles of sharia. It shares the benefits and losses both in fund raising and murabahah financing and in service products. However, in its implementation, Sharia Bank has not yet applied the distribution of profit and loss in murabahah financing based on justice. Sharia Bank in finance products apply a lot of buying and selling principles of murabahah, which means the practice is the same as interest in conventional Banks. Murabahah financing implementation illustrates a severe problem in sharia banking law in Indonesia, it is about injustice.
\end{abstract}

\section{Keywords: Murabahah, Sharia Bank, and Islamic Justice}

\section{A. INTRODUCTION}

Syariah Bank is a business entity engaged in financial services which its activities are collecting funds and distributing it to the community and other economic activities in the form of services. Moreover, it can receive zakat, infaq and sadaqah and distribute it to the right people.

Sharia Bank is the ideal institution seen from philosophically, juridically and sociologically. ${ }^{1}$ Philosophically, Syariah Bank is a financial institution in accordance with the ideology of the Indonesian nation, namely Pancasila from the first to the fifth precept and the opening of the 1945 Constitution ${ }^{2}$. More powerful philosophically is in accordance with the Qur'an and Hadith.

Sharia Bank juridically in accordance with existing legislation in Indonesia, namely Law Number 7 Year 1992 concerning Banking which is accompanied by the birth of Government Regulation Number 72 Year 1992 concerning Bank Based on Profit Sharing Principle. Then the Act is amended by Act Number 10 of 1998 concerning Banking, and then regulated with its

\footnotetext{
Mustaghfirin, Rekonstruksi Sistem Hukum Perbankan di Indonesia Kajian Dari Aspek Filososfis, Sosiologis dan Budaya, Unissula Press, Semarang, 2006, page. 9-16 dan Dadan Muttaqien, Sistem Perbankan Syariah di Indonesia dalam Perspektif Politik Hukum, Disertasi, Universitas Diponegoro, Semarang, 2007, page. 361.

2 Ibid., page. 9-16 dan Dadan Muttaqien, Ibid., page. 361.
}

own legislation, namely Law Number 21 Year 2008 concerning Sharia Banking. In addition to legislation, sharia banking is also regulated in the Bank Indonesia Regulation, the Compilation of Islamic Economic Law and the Fatwa of the National Sharia Council.

The Sharia Bank is sociologically appropriate to the needs of the Indonesian people. First, the majority of Indonesians are Muslims who need a bank in accordance with the Islamic principle of sharing profit and loss. The second is shariashare pricing practices are already part of the culture of Indonesian society in various economic activities applying "maro, mertelu"3. According to Dadan Muttaqien, sharia banking has become sine quanon, its existence in Indonesia, because it is in accordance with national culture and business activities run by the nation of Indonesia.

The Sharia Bank still implements such interest in conventional or unfair banks. The ideal Sharia Bank is in fact still a weakness, especially in terms of the practice of Sharia Bank products. According to Renny Supriyatni B. in her dissertation, "Shared Financing Sharing Agreement for Sharia Banking Efforts" found that Sharia Banks in financing with profit-sharing system, in its practice applies revenues sharing. It means that the mechanism is a profit-sharing calculation based on in the total revenue received 3 Dadan Muttaqien, Ibid., page. 361. 
by the customer before deducting the expenses incurred by the customer to obtain the income, here, there is no loss sharing. ${ }^{4}$ Atin Meriati Isnaini in her dissertation "Reconstruction of the Principle of Justice in Financing Agreements with a Partnership System in Syariah Banking" found that Sharia Banks in financing products apply much of the principle of buying and selling murabaha that the practices are similarly to interest in conventional banks. ${ }^{5}$

The result of the dissertation shows that the Shariah Bank's products are still applying interest or not applying the advantages and disadvantages. It contradicts with the findings of Dadan Muttaqien and Mustaghfirin who found that Shariah Bank is ideally in philosophically, juridically and sociologically. Furthermore, it is strengthened by Umar Chapra that the implementation of sharia bank is not in accordance with the maqaasid sharia, while Samid Homoud said that the current Sharia Bank still applies the interest. ${ }^{6}$

Based on the background for the above research, the writer formulated several problems as how is the application of the law regarding the sharing of profits and losses in murabahah financing at Sharia Bank Indonesia based on the Islamic Law justice perspective. And why is the application of the law regarding the sharing of profit and loss in murabahah financing at Sharia Bank Indonesia has not provided justice?

\section{B. DISCUSSION}

1. Implementation of law concerning sharing of profit and loss in murabahah financing at Sharia Bank Indonesia based on justice of Islamic Law perspective

Murabahah financing at Sharia Bank is measured from the Islamic legal values of

4 Renny Supriyatni B., Perjanjian Bagi Hasil Dalam Pembiayaan Yang Berkeadilan Sebagai Upaya Pembangunan Bank Syariah, Pasca Sarjana UNPAD, 2009, page. 247-268.

5 Atin Meriati Isnaini, Rekonstruksi Prinsip Keadilan Dalam Aqad Pembiayaan Dengan Sistem Kemitraan di Perbankan Syariah, Disertasi, Pasca Sarjana, Universitas Brawijaya, Malang, 2013, diakses pada http://hukum.ub.ac.id/disertasi-atin-upaya-rekonstruksiprinsip -keadilan-dalam-perbankan syariah/ 20-05-2014.

6 Samid Homoud, Progres of Islamic Banking, The Aspiration and The Realities" Islamic Economic Studies, Vol. 2 No. 1, 1994.
Abul A'la al-Maududi ${ }^{7}$ which is strengthened by Mannan ${ }^{8}$ and also Ascarya, it does not fulfill three elements, namely: First, profit taking is based on the existence of the business undertaken. Secondly, there is responsibility for the business which he undertakes as in the usul fiqh's kaedah is called as "the luck of accompanying responsibility and for loss (al-kharaj bi al-daman)" ${ }^{9}$. Thirdly is the existence of shared risks borne. Some injustices in murabahah financing are:

a. The Customer shall bear the total risk from the purchase of the goods until the goods are present to the customer while the Sharia Bank does not want to bear the risk;

b. Sharia Banks take advantage that is not according to sharia, the profit making in sharia is allowed as long as there is effort executed, there is division of responsibility and entrepreneur ready to bear risk;

c. The Customer shall be liable for administrative, notary, and insurance expenses which should be the responsibility of sharing if the profit and loss are shared;

d. The existence of engineering contracts, namely in the agreement mentioned buying and selling of goods, but in fact, it is the debt of money that must be returned by customers by adding interest on demand by the Sharia Bank;

e. The unjust model of debt repayment, such as the interest-decrease rate model, so that if the customer pays off early, the customer will be burdened with a large and abysmal principal, which, when compared to the flat

7 Abul A'la al-Maududi, Riba, terjemahan Abdullah Suhaili, Hudaya, Jakarta, 1970, page. 23.

8 Muhammad Abdul Mannan, Islamic Economics, Theory and Practice, terjemahan M. Nastangin, Teori dan Praktik Ekonomi Islam, Dana Bhakti Wakaf, Yogyakarta, 1995, page. 205.

9 Frank E. Vogel dan Samuel L. Hayes, III, Islamic Law And Finance : Religion, Risk, And Return, Kluwer Law International, Cambridge, Massachusetts, 1998, terjemahan M. Sobirin Asnawi, Siwi Purwandari dan Waluyati Handayani, Hukum Keuangan Islam : Konsep, Teori dan Praktik, Nusamedia, Bandung 2007, page. 138. 
debt repayment of both the principal and the interest, then the customer is liable to pay the interest penalty one installment;

f. Sale-buy murabaha sense of lending and borrowing money. Sharia Bank is actually lending-borrowing money wrapped with a contract of buying and selling murabaha;

g. The Sharia Bank does not make a real business but as a broker. The Sharia Bank is merely an intermediary between the investor and the business world so it does not make a real effort;

h. Sharia Banks do not share the risk. It is promised in the contract that the client is responsible for the goods purchased by the customer, including his documents or proof of ownership and the Sharia Bank is liable to be responsible for the risk of the goods, whereas it is the bank that is the buyer and the bank is also responsible for the risk ;

i. Taking advantage of murabahah financing at Sharia Bank based on loan size, length of time of interest and interest rate of Bank Indonesia;

j. When comparing conventional bank loans with murabaha financing in Sharia Bank, it would appear that conventional banks take profits on loans based on loan size, length of time of financing, inflation and interest rates of Bank Indonesia, as well as Sharia Banks in financing the financing of mura- bahah;

k. The Sharia Bank represents customers for the purchase of goods in the absence of benefits. Murabahah financing practices in Sharia Bank in terms of purchasing goods are always represented to customers, so the bank asks customers who are responsible for the risks, but in the execution of purchases of goods, customers never get the rewards of money.
2. For the application of the law regarding the sharing of profits and losses in murabahah financing in Sharia Bank Indonesia has not provided justice

Factors cause injustice in the application of share of profit and loss on murabahah financing, namely the factor of legal substance, legal structure factors and legal culture factors.

a. Factors of legal substance, namely:

1) The existence of two contradictory regulations, namely the unfair interest-based conventional banking law and a sharia-based banking law that shares fair benefits and losses;

2) The contents of the sharia banking law materials that have not been regulated in their articles on murabahah that share the advantages and disadvantages;

3) MUI fatwa and Bank Indonesia regulation governing murabahah financing as a weak regulation in hierarchy of legislation.

b. The legal structure, among others:

1) The existence of contradictory dualism of banking institutions, namely conventional banking and sharia banking;

2) Sharia Banks apply more formal justice than substantial justice in murabahah financing;

3) Sharia Banks are still in capitalist paradigm and have not Islamic paradigm in murabaha financing;

4) Sharia Bank aims to avoid usury rather than eliminate usury in murabaha financing;

5) Sharia Bank does not want to apply share loss in murabahah financing but wants to continue profit;

6) Sharia Bank implements a pragmatic murabaha financing law so as to lack justice;

7) Competitive factor between sharia bank and conventional bank;

8) Policy factor of commissioner or shareholder in Sharia Bank that 
is not in accordance with Sharia principles, ie not willing to bear losses;

9) Sharia Supervisory Board Factor is weak in supervising murabahah financing in Sharia Bank.

c. Legal culture or legal culture, among others:

1) The weak factor of some banking experts about usury;

2) Factors of some customers or people who have pragmatism of capitalism;

3) The weak factor of public knowledge on Sharia Bank products;

4) The factor of currency value is always inflation and not guaranteed with stable gold.

3. Reconstruction of law concerning application of share of profit and loss in murabahah financing at Sharia Bank Indonesia based on justice perspective value of Islamic Law.

a. Reconstruction of Values

Reconstruction of value found the theory that researchers call it as the theory of ta'awun wa tawazun, that is sharing of fair profit and loss with the formula of three criteria, that is (1) existence of effort, (2) existence of responsibility (3) risk sharing formulated as follows:

The advantages of murabaha murabaha or loss are: $x$

1) Principal capital symbolized: $m$

2) The existence of business symbolized: y1

3) Responsibility symbolized: $y 2$

4) Assume symbolic risk: $y 3$

The advantage of murabaha is: $x=$ $m+y 1+y 2-(-y 3)$

Murabahah loss is: $x=m+y 1-y 2$ $-(+y 3)$

Example murabaha profit: 100million

+10 million +10 million +10 million

$=130$ million

Example murabahah loss: 100million

+10 million -10 million - (+10million)

$=90$ million b. Reconstruction of Law Number 21 Year 2008

Islamic Bank according to Islamic Law has fulfilled the requirements of fiqhiyah namely "al-yaqinu la yuzalu bi al-syakki10", it means that the belief eliminates doubt because it has been regulated by Law Number 21 Year 2008. However, when it sees from the side of more chapters detailed, sharia banking law is not yet clears the justice of sharing profit and loss as fiqhiyah "al-umuru bi maqasidiha ${ }^{11 "}$ principles. It means that law must be according to its purpose-justice. The juridical justice is correct, but there are no details explaining the justice of sharing profits and losses. So Article 2 plus equity shares the advantages and disadvantages, so that it sounds sharia banking in doing its business activities is based on the principles of shariah which equitably shares the advantages and disadvantages, economic democracy and prudential principles.

Article 19 letter $d$ added mudharabah wal mura-bahah contract, musyarakah wal murabahah contract, musyarakah wa ijarah al-muntahia bit-tamlik, so it reads: distributing fee based on murabaha, mudharabah wal murabaha, musyarakah wal murabaha, musyarakah wa ijarah al-muntahia bit-tamlik, akad salam, akad istishna ', or other contract that is not contrary to sharia principles.

c. Reconstruction of Article 3 Subarticle (b) of Bank Indonesia Regulation Number 9/19/PBI/2007 and Amendment in Bank Indonesia Regulation Number: 10/16/PBI/2008

Bank Indonesia Regulation is a regulation made based on the custom carried out in the sharia banking. This custom is in the Fatwa of the Indonesian Ulama Council through the National Sharia Council, which is about Murabahah Number 04 / DSN-MUI / IV / 2000 on Murabahah, this is in accordance

10 Abdul Hamid Hakim, Mabadi' Awwaliyah, Sa'diyah Putra, Jakarta, page. 26.

11 Ibid., page. 22. 
with the fiqhiyah principles, that is "al'adatu muhakkamah" ${ }^{12}$ meaning the behavior becomes a law. Based on the aforementioned fiqhiyah, Bank Indonesia Regulation Number: 9/19 / PBI 2007 Article 3 letter (b) and its amendment in Bank Indonesia Regulation Number: 10/16/PBI/2008 have not regulated the fair murabaha of profit and loss. Therefore ideally the regulation should add the chapter sounds to Article 3 letter (b) which regulate mudaraba wal murabaha, musyarakah wal murabaha and musyarakah wa ijarah al-muntahia bit-tamlik.

d. Reconstruction of Equitable Murabahah Financing for Profit and Loss

Based on the reconstruction, the researcher found that the Sharia Bank has not implemented a fair murabahah financing to share the profit and loss. Thus, according to the jurisprudence of fiqhiyah "la dharara wala dhirara ${ }^{13}$ ", it means no harm and no harm or equality or equity between Sharia Bank and customer it is concluded that murabahah financing practiced by Sharia Banks requires new construction of murabahah financing which equitably shares the advantages and disadvantages.

The researchers offer a new construction of a fair murabaha financing application sharing profits and losses at Sharia Bank Indonesia. The new construction of a fair murabaha financing application shares the advantages and disadvantages of Sharia Bank Indonesia as follows:

1) Mudharabah Wa Al-Murabahah ${ }^{14}$ Mudharabah wa al-murabahah model financing is intended for customers who will buy goods but have no money at all. Customers who do not have any money at all, the Sharia

12 Ibid., page. 37.

13 Abdul Hamid Hakim, al-Sullam, Sa'diyah Putra, Jakarta, page. 59.

14 Ascarya, Akad \& Produk Bank Syariah, Raja Grafindo Persada, Jakarta, 2007, page. 210.
Bank can make mudharabah wal murabaha, the customer is required to purchase goods as a representative of Sharia Bank and the customer is given profit in the form of discounted price of goods already obtained for sale to the customer at cost plus profit margin.

2) Musyarakah Wal Murabahah ${ }^{15}$ Musyarakah wal bai 'murabahah model financing is for customers who have some funds, but not enough to purchase goods. Customers who only have a portion of the funds to purchase Sharia Bank goods can provide financing with musyarakah wal bai 'murabaha model, ie customers and Sharia Banks equally spend capital for purchasing goods, so Sharia Bank asks customers as joint representatives to buy goods and after goods get sold to customers who really need the goods. The profit result is shared and the losses incurred are shared between the Sharia Bank and the customer.

3) Musyarakah Wa ljarah AlMuntahia Bit-Tamlik

Financing model musyarakah wa ijarah al-muntahia bit-tamlik is reserved for customers who have a fund but not enough for the purchase of goods. Customers who only have a portion of the funds to purchase goods, the Sharia Bank can provide financing with the musyarakah wa ijarah al-muntahia bit-tamlik model, ie customers and Sharia Banks equally spend capital for purchasing goods, so Sharia Bank asks customers as joint representatives to buy goods and after the goods obtained, leased to customers who really need the goods. The profit result is shared and the losses incurred are shared between the Sharia Bank and the customer.

15 Ibid., page. 213 


\section{CONCLUSION}

The law application regarding the sharing profits and losses in murabahah financing in the Sharia Bank Indonesia based on justice perspective of Islamic Law has not been done. Murabahah financing at Sharia Bank Indonesia does not apply the law of sharing profit and loss fairly based on values in Islamic law. The Sharia Bank does not apply profits based on three criteria, namely the existence of business, the sharing of responsibilities, and the sharing of risks. Sharia Bank executing murabahah financing products with the steps of customers are required to represent the Sharia Bank to find the goods themselves are required, as well as responsible for all risks that are generated. Then after getting goods in the form of a house or car is considered the property is owned by Sharia Bank, then sold to the customer with the cost of the principal plus the profit margin and the customer shall bear all costs starting from administration, insurance, guarantee binding fee and stamp duty. The profit is determined by the Sharia Bank and the customer is only served with a debt agreement with the customer paying monthly installments. The installment model applied by the Sharia Bank is the same as the conventional bank that interest decreases. Based on the application of murabahah financing.

Because the application of the law regarding the sharing of profit and loss in murabahah financing in Sharia Bank Indonesia has not provided justice because of three factors, namely weakness in terms of legal substance, legal structure and legal culture. The weakness of the substance of the law, namely the existence of two-banking regulations that contradiction $100 \%$ of the law on conventional banking interestbased unfair and sharia-based law on the basis of sharing the benefits and losses fair. Sharia banking law set about share the advantages and disadvantages of its philosophy in Article 1 and have not regulated in more detailed articles, and the business activities of Sharia Banks are only regulated through the Fatwa of the Indonesian Council of Ulama, namely the fatwa of the National Sharia Council as well as in the Bank Indonesia regulation, hierarchy of legislation so that its position is less powerful force. The weaknesses that exist within the legal structure, including the existence of the banking system's dualism are $100 \%$ contradiction, the factor of Sharia Bank is trapped in the application of formal justice and does not apply substantial justice, the factor of Sharia Bank which is still capitalist paradigm and not use Islamic paradigm. One of the objectives of Sharia Bank management is to avoid usury and eliminate usury, the factor of Sharia Bank which wants only profit and do not want to lose, the factor of Sharia Bank which keeps the implementation of law about pragmatic murabaha financing, competitiveness factor between Syariah Bank and conventional bank, the policy of commissioners or shareholders which do not comply with sharia or do not want to lose and factor Sharia Supervisory Board is weak in supervision to the Sharia Bank. The weak culture or legal culture, including: the weak factor of understanding some Islamic banking experts about usury, customer or community factors that partially capitalism pragmatism paradigm, the weak factor of understanding of society to the product of Sharia Bank, and currency value factor that always inflation and has not been secured by stable gold.

The reconstruction of the law regarding the application of the share of profit and loss in murabahah financing in the Sharia Bank Indonesia based on the perspective of justice value Islamic law is the discovery of a new theory called the ta'awun wa tawazun theory, which is a fair murabaha financing share the advantages and disadvantages with three criteria that is (1), (2) responsibility, (3) risk sharing, the formulated murabahah profit is $X=M+$ $y 1+y 2-(-y 3)$ and the murabaha loss is $X=$ $M+y 1-y 2-(+y 3)$. Law Number 21 of 2008 concerning Sharia Banking Article 2, together with a fair sharia principles of profit and loss become a Sharia Bank in conducting its business activities based on sharia principles that share equitable advantages and disadvantages, economic democracy and prudential principles. Then Article 19 letter (d) is added so as to read: to distribute financing based on murabahah, mudharabah wal murabaha, musharaka ak al-muntahia bit-tamlik, does not conflict with sharia principles and reconstructs Bank Indonesia 
Regulation Number 9/19/PBI/2007 concerning the Implementation of Sharia Principles in Funds and Disbursement Activities and Sharia Bank Services Article 3 letter (b) and amendments in the Bank Regulation Indonesia Number: 10/16 / PBI / 2008 becomes Article 3 letter (b) added by arranging therein mudharabah wal mura-bahah , musyarakah wal murabaha and musyarakah wa ijarah al-muntahia bit-tamlik. Implementation of the reconstruction result, namely murabahah wal mudharabah, musyarakah wal murabaha and musyarakah wa ijarah al-muntahia bit-tamlik, that the financing mudharabah wal murabaha model is intended for customers who will buy goods but have no money at all, Islamic Banks can mudharabah wal murabaha, the customer is required to buy goods as a representative of Sharia Bank and the customer is given a profit in the form of discounts then the goods that have been obtained is sold to the customer with the cost of goods plus the profit margin with the first stage of mudharabah contract to get the goods, then the second stage of the contract murabaha. The financing of musyarakah wal murabaha model is intended for customers who have some funds but not enough to purchase goods. Sharia Bank can provide financing with the murabaha wal murabahah model, ie customers and Sharia Banks equally spend their capital for purchasing goods, Sharia Bank requests customers as joint representatives to buy goods and after the goods obtained are sold to customers who really need the goods. The profit result is shared and the losses incurred are shared between the Sharia Bank and the customer. The cost model of musyarakah wa ijarah almuntahia bit-tamlik is reserved for customers who have some funds but not enough for the purchase of goods, Sharia Bank can provide financing with model musyarakah wa ijarah almuntahia bit-tamlik, that is customer and Bank Shariah equals to spend capital for purchasing goods, so Sharia Bank asks customers as joint representatives to buy goods and after the goods obtained, leased to customers who really need the goods. The profit result is shared and the losses incurred are shared between the Sharia Bank and the customer.

Syariah banking practitioners should implement fair Islamic legal values by sharing the advantages and disadvantages in murabahah financing free of usury. Murabahah financing can be replaced by applying mudharabah wa almurabahah, musyarakah wa al-murabahah and musyarakah wa ijarah al-muntahia bit-tamlik, The legislature should make more detailed changes in the drafting of sharia banking laws and the time has to be changed because it has long been enacted and needs to be revised and People using Sharia Bank products should be aware of their products so that they do not feel any fraud in transacting.

\section{BIBLIOGRAHY}

Abdul Hamid Hakim, al-Sullam, Sa'diyah Putra, Jakarta. , Mabadi 'Awwaliyah, Sa'diyah Putra, Jakarta.

Abul A'la al-Maududi, 1970. Riba, the translation of Abdullah Suhaili, Hudaya, Jakarta.

Ascarya. 2007. Akad \& Produk Bank Syariah, Raja Grafindo Persada, Jakarta.

Frank E. Vogel and Samuel L. Hayes, III. 2007. Islamic Law And Finance: Religion, Risk, And Return, Kluwer Law International, Cambridge, Massachusetts, 1998, translation of M. Sobirin Asnawi, Siwi Purwandari and Waluyati Handayani, Islamic Finance Law: Concepts, Theory and Practice, Nusamedia, Bandung.

Muhammad Abdul Mannan. 1995. Islamic Economics, Theory and Practice, translation of M. Nastangin, Theory and Practice of Islamic Economics, Dana Bhakti Wakaf, Yogyakarta.

Mustaghfirin. 2006. Reconstruction of Banking Law System in Indonesia Study Of Philosophical, Sociological and Cultural Aspects, Unissula Press, Semarang. 
Renny Supriyatni B. 2009. Profit Sharing Agreement in Just Financing as the Development Effort of Bank Syariah, Post Graduate UNPAD.

Dadan Muttaqien. 2007. Sharia Banking System in Indonesia in Political Perspective of Law, Dissertation, Diponegoro University, Semarang.

Samid Homoud. 1994. Progress of Islamic Banking, The Aspiration and The Realities "Islamic Economic Studies, Vol. 2 No. 1.

Atin Meriati Isnaini, Reconstruction Principle of Justice In Aqad Financing With Partnership System in Syariah Banking, Dissertation, Post Graduate, Universitas Brawijaya, Malang, 2013, accessed at http://hukum.ub.ac.id/disertasi-atin-upaya-rekons traction-principle. 